\title{
A Critical Review of Concept of Lasika in Ayurved w.s.r. to Interstitial Fluid
}

\author{
Review Article
}

\section{Saylee Deshmukh ${ }^{1 *}$, Sachin Chandaliya ${ }^{2}$, Baghel $M S^{3}$}

1. Research Officer, RRAP Central Ayurved Research Institute for Cancer, CCRAS, Mumbai-India.

2. Professor \& Head, Department of Panchakarma, Shri Ayurved Mahavidyalaya, Nagpur-India.

3. Ex-Director, IPGT\&RA, Gujarat Ayurved University, Jamnagar-India.

\begin{abstract}
Ayurveda is a science which was in dynamic continuum of development like all sciences. However due to various geopolitical and social reasons after $5^{\text {th }}$ Century true development of Ayurveda science has stagnated hence few terms and concepts remain unexplained. Therefore a lot of concepts in Ayurved are there which need more understanding from modern physiological point of view. The concept of Lasika is one of them. It is a physiological entity, said to be the seat of Pitta, Mala of Rasa Dhatu and play major role in the pathological conditions like Kushtha, Visarpa, Vrana, Dagdha and most importantly in Prameha. The present article aims at exploration of concept of Lasika in Ayurved and its comparison with interstitial fluid on the basis of its modern physiological resemblance. This also be required to be discussed whether Lasika is Dhatu, Upadhatu or Mala.
\end{abstract}

Keywords: Lasika, Inflammation, Prameha, Mala.

\section{Introduction:}

Following are references and view point regarding Lasika in classical texts.

- Lasika has been defined in clinical point of view as 'fluid which oozes out from the wound.'(1)

- Lasika has been described as Mala of Rasa Dhatu (2) and site of Pitta i.e. physiologically it exhibit functions of Pitta.

- It is also stated that when due to Ushna (hot) property of Pitta, the liquid part is secreted from Mamsa Dhatu by fomentation, it is called as Lasika. (3)

- It is also considered as Upadhatu along with Stanya, Artava.(4)

- It is said to be the liquid part residing in between the layers of Tvak and Mamsa.(5)

- Lasika is also narrated as Pichchha Bhaaga of Udaka indicating fluid with sticky nature or may indicate residue.(6)

- It is mostly Jalaprayah in nature i.e. predominantly contains water.(7)

- Though it is explained as a part of Udaka Dhatu, the terms Sweda and lasika are explained separately which indicate that it is a separate entity than Udaka itself(1). Lasika is also said to be having the nature of Vilina Medah Prayam (8) (appears like melted fat).

- Lasika is one the factors involved in pathology of

*Corresponding Author:

\section{Saylee Deshmukh}

RRAP Central Ayurved Research Institute for Cancer, Podar Medical (Ayurved) College Campus, Worli, Mumbai

Email: dsaylee@ymail.com
Prameha (9) and mainly in a type of Vataja Prameha named Hastimeha.(10) It is mentioned in continuity along with other liquid biological factors like Oja, Rasa, Shukra, Shonita (8) indicating separate biological structure than others.

Vitiation of Lasika occurs in the diseases like Vicharchika, Visarpa, Pundarika Kushtha, Dagdha which have dominance of Pitta. Lasika is explained in Vrana srava (exudates from ulcers) along with Pooya, Jala, Asruka (11) again indicating the separate entity than all the others explained there.

The term Lasika used in Kushtha Nidana (12) is replaced by the word $A m b u$ in Kushtha chikitsa chapter (13) while explaining Dosha-Dushya Samgraha. It is also explained as which oozes out of the skin in the disease conditions like types of Kushtha- Kapala (14), Audumbar (15), Pundarika (16), Sidhma (17), and Asadhya Lakshana (18) along with other pathological secretions like Pooya, Rakta. Thus, it is evident that it is completely different entity than blood and pus.

In Karna Roga, in Pakva condition i.e. when acute inflammatory stage gets subsided, secretion of Lasika gets reduced (19). In Kaphaja Shotha also, if someone gets hurt on the Shotha, blood does not ooze out. Instead, after some period of time, Pichha starts secreting out which is also known as Lasika (20).

In nutshell-

1. Lasika is considered as liquid component having separate entity other than Udaka /Jala, Rasa, Shonital Rakta, Pooya.

2. The physical nature of Lasika is viewed differently by different scholars. It looks turbid (6) or clear (21).

3. Lasika is said to be the seat of Pitta.

4. It is also considered as Mala of Rasadhatu and having the nature of Upadhatu. 
5. It comes out of the skin after various types of injuries like burns, wounds and oozes out as secretions in some skin diseases.

6. It is oozing out in various clinical conditions like Audumbar Kustha, Vrana, Visarpa, Dagdha which mostly are having Pitta dominance.

In comparison with the modern science, fluid which oozes out from the wound is an inflammatory exudate in response to the wound. Present article aims to elaborate the concept of Lasika in Ayurved and in comparison with interstitial fluid in various aspects.

\section{Interstitial fluid}

Extracellular space is filled with a composite material, known as the extracellular matrix, composed of gel which is known as the interstitial fluid. Interstitial fluid is by far major component of Extracellular fluid (ECF). It is the fluid solution that bathes and surrounds the cell. It is found in interstitial spaces (22). Interstitial fluid consists of a water solvent containing sugars, salts, fatty acids, amino acids, coenzymes, hormones, neurotransmitters, white blood cells and waste products from the cell. This water solvent accounts for $26 \%$ of the water in the human body (23). Interstitial fluid (IF) is created by trans-capillary filtration and cleared by lymphatic vessels. It transports nutrients and waste products between cells and blood capillaries, signaling molecules between cells, and antigens and cytokines to local draining lymph nodes for immune regulation. Its alterations are fundamental to changes in cell function in inflammation etc pathologies (24).

\section{Piccha as synonym of Lasika (21)}

Word Piccha stands for sliminess and Vilina Meda Prayah indicates its semi-transparent form. According to Ayurved, Lasika is viscous in nature. Polysaccharides or glycans in extracellular matrix which attracts the water molecules are responsible for its gel like quality (25) which is slimy and semi-transparent in nature.

\section{Lasika as Pittasthana (26)}

Lasika has been described as seat of Pitta i.e. physiologically it exhibit functions of Pitta. Pitta is one of the three Doshas described in texts of Ayurveda. Doshas, in balanced state execute their normal functions in the body. But they are actual intrinsic factors which are responsible for disease manifestation when they get imbalanced due to extrinsic factors (27). Interstitial fluid is most important part of extracellular space. The composition of the extracellular space includes metabolites, ions, various proteins and non-protein substances that might affect cellular function. For example, hormones, growth factors, cytokines and chemokines act by travelling the extracellular space towards biochemical receptors on cells. Other proteins that are active outside the cell are various enzymes, including digestive enzymes (Trypsin, Pepsin), extracellular proteinases and antioxidant enzymes. Often, proteins present in the extracellular space are stored outside the cells by attaching to various extracellular matrix Proteoglycans, etc.) (28).

\section{Lasika as Dhatu (1) and Upadhatu (4)}

Lasika has been described as Udaka Dhatu. According to texts of Ayurved, Dhatu has been considered as such entity which plays very important role to support the body structurally as well as functionally (29). Interstitial fluid provides means of delivering materials to the cells, intercellular communication which is an important function in body. But Acharya Vagbhat considered it as Upadhatu which has minor function as compared with Dhatu (30) maybe due to its less important functions as compared to other body tissues. Glycolysis is the metabolic pathway that converts glucose into pyruvate. The free energy released in this process is used to form the high-energy molecules ATP (adenosine triphosphate) and NADH (reduced nicotinamide adenine dinucleotide). Glycolysis occurs in most organisms in the cytosol of the cell. But in a condition of cell death, glycolysis occurs in interstitial fluid as Lactate dehydrogenase (LDH) is present in interstitial fluid (31). According to Ayurved, Prinana which can be correlated with ATP release in the cell is a function of Rasa Dhatu. Cytosol can be correlated with Rasa Dhatu on the basis of its function. Interstitial fluid has nourishing function less than as compared with cytosol.

\section{Lasika as Mala of Rasa Dhatu}

Lasika has been quoted as Mala of Rasa Dhatu. According to Ayurved classics, Mala means waste product. Interstitial fluid plays important role in removal of waste products produced by metabolic activities of cell.

\section{Role of Lasika in pathogenesis of Vataja Prameha}

Hyperglycaemia in untreated diabetics results in ECF which is both hyperosmolar and hypertonic. The rise in interstitial fluid osmolarity causes fluid shift from the ICF to the ECF. In this condition, water moves out of the cells because of which cell shrinks in size which is called as hyperosmotic dehydration and glucose cannot easily enter cells because of affected cell permiablity (32). According to texts of Ayurved, Lasika is involved in Vataja Prameha which is later stage of Prameha. The pathological condition of Lasika in Prameha has been described as 'Atibahutvat Lasika' (33) i.e. Lasika increases in volume which can be correlated with above explanation of increase in volume of interstitial fluid which occurs in untreated or later stage of Diabetes mellitus.

\section{Lasika Dushti}

According to Ayurved classics, vitiation of Lasika has been mentioned in diseases like Vicharchika (34) i.e. Wheeping eczema (35), Visarpa (36) i.e. Erysepalus (37), Pundarikakustha (38) i.e. Discoid lupus erythematous (39). In all these conditions, inflammation is a common factor. As per the definition of 'Lasika' given in Charak Samhita, it is the fluid which is emitted from the Vrana i.e. wound. In the context of wound, exudates are emitted which can be either serous for mild 
inflammation or purulent for severe inflammation. Inflammation occurs as a response in the wound healing (40). In the process of inflammation, interstitial fluid plays very important role. The colloid osmotic pressure of interstitial fluid gets increased in relative terms to plasma, suggesting a significant buffering capacity against edema formation, and also that there is a significant local production of pro-inflammatory mediators to a systemic inflammatory stimulus. Inflammatory stimuli may furthermore result in a rapid reduction in interstitial fluid pressure, thus leading to increased filtration and edema formation (41). C-reactive protein which is a biomarker of inflammation (42) can be taken as biomarker for assessment of Lasika Dushti.

\section{Conclusion}

On the basis of similarities between Lasika and interstitial fluid, in respect to their nature, functions and pathological aspect, it can be concluded that interstitial fluid may be considered as Lasika.

\section{References}

1. Acharya Y.T., Charaka Samhita, reprint edition, Sharirasthana, Ch.7, Ver.15, Ayurved-dipika commentary by Chakrapani, Chaukhamba Orientalia, Varanasi, 2007, p.339

2. Atridev Gupta, editor, Ashtang Sangraha, Sharirasthana. Reprint edition. Ch. 6, Ver. 44, Chaukhamba Krushnadas Academy: Varanasi; 2011, Vol. I, p.311

3. Acharya Y.T., Sushrut Samhita, reprint edition, Sutrasthana, Ch.21, Ver.7, Nibandhasamgraha commentary by Dalhana, Chaukhamba Surbharati, Varanasi, 2012, p.100

4. Acharya Y.T., Sushrut Samhita, reprint edition, Sutrasthana, Ch.4, Ver.5, Nibandhasamgraha commentary by Dalhana, Chaukhamba Surbharati, Varanasi, 2012, p.17

5. Acharya Y.T., Charaka Samhita, reprint edition, Nidanasthana, Ch.4, Ver.37, Ayurved-dipika commentary by Chakrapani, Chaukhamba Orientalia, Varanasi, 2007, p.215

6. Acharya Y.T., Charaka Samhita, reprint edition, Sutrasthana, Ch.20, Ver.8, Ayurved-dipika commentary by Chakrapani, Chaukhamba Orientalia, Varanasi, 2007, p.113

7. Paradakar SH, editor. Ashtang Hridaya, Sutrstahana, Reprint edition. Ch. 12, Ver. 2, Ayurvedarasayana commentary by Hemadri, Varanasi: Chaukhamba Sanskrit Sansthan; 2010. p.192

8. Shivprasad Sharma, Ashtang Samgraha, 3rd edition, Nidanastahana, Ch.10, Ver.13, Shashilekha commentary by Indu, Chaukhamba Samskrit Series, Varanasi, 2012, p.393

9. Acharya Y.T., Charaka Samhita, reprint edition, Nidanasthana, Ch.4, Ver.7, Ayurved-dipika commentary by Chakrapani, Chaukhamba Orientalia, Varanasi, 2007, p.212

10. Acharya Y.T., CharakaSamhita, reprint edition, Nidanasthana, Ch.4, Ver.37, Chaukhamba Orientalia, Varanasi, 2007, p.215
11. Acharya Y.T., Charaka Samhita, reprint edition, Chikitsasthana, Ch.25, Ver.28, Ayurved-dipika commentary by Chakrapani, Chaukhamba Orientalia, Varanasi, 2007, p.593

12. Acharya Y.T., CharakaSamhita, reprint edition, Nidanasthana, Ch.5, Ver.3, Chaukhamba Orientalia, Varanasi, 2007, p.216

13. Acharya Y.T., Charaka Samhita, reprint edition, Chikitsasthana, Ch.7, Ver.9, Ayurved-dipika commentary by Chakrapani, Chaukhamba Orientalia, Varanasi, 2007, p.450

14. Acharya Y.T., Charaka Samhita, reprint edition, Nidanasthana, Ch.5, Ver.8/1, Ayurved-dipika commentary by Chakrapani, Chaukhamba Orientalia, Varanasi, 2007, p.218

15. Acharya Y.T., Charaka Samhita, reprint edition, Nidanasthana, Ch.5, Ver.8/4, Ayurved-dipika commentary by Chakrapani, Chaukhamba Orientalia, Varanasi, 2007, p.218

16. Acharya Y.T., Charaka Samhita, reprint edition, Nidanasthana, Ch.5, Ver.8/5, Ayurved-dipika commentary by Chakrapani, Chaukhamba Orientalia, Varanasi, 2007, p.218

17. Acharya Y.T., Charaka Samhita, reprint edition, Nidanasthana, Ch.5, Ver.8/6, Ayurved-dipika commentary by Chakrapani, Chaukhamba Orientalia, Varanasi, 2007, p.218

18. Acharya Y.T., Charaka Samhita, reprint edition, Nidanasthana, Ch.5, Ver.10, Ayurved-dipika commentary by Chakrapani, Chaukhamba Orientalia, Varanasi, 2007, p.218

19. Paradakar SH, editor. Ashtang Hridaya, Uttarasthana, Reprint edition. Ch. 17, Ver. 3, Varanasi: Chaukhamba Sanskrit Sansthan; 2010, p. 835

20. Paradakar SH, editor. Ashtang Hridaya, Nidanasthana. Reprint edition. Ch. 13, Ver. 36, Ayurvedarasayana commentary by Hemadri, Varanasi: Chaukhamba Sanskrit Sansthan; 2010. p. 521

21. Paradakar SH, editor. Ashtang Hridaya, Sutrasthana. Reprint edition. Ch. 12, Ver. 2, Sarvangasundari commentary by Arunadatta, Varanasi: Chaukhamba Sanskrit Sansthan; 2010. p. 192

22. Bernard M. Garrett; Fluids and Electrolytes; Routledge, Taylor \& Francis publishing group, New York, 2017, p.14

23. Widmaier, Eric P., Hershel Raff, Kevin T. Strang, Arthur J. Vander; Body Fluid Compartments; Vander's Human Physiology: The Mechanisms of Body Function. 14th ed. New York: McGraw-Hill, 2016. 400-401

24. Wiig H, MA Swartz; Interstitial fluid and lymph formation and transport: physiological regulation and roles in inflammation and cancer; Physiological reviews, 2012. p.1005-1060

25. The Cell; edited by Kara Rogers; Biomedical Sciences, The Rosen Publishing Group, New York, 2011; p.105.

26. Acharya Y.T, Charaka Samhita, reprint edition, Sutrasthana, Ch.20, Ver.8, Ayurved-dipika 
commentary by Chakrapani, Chaukhamba Orientalia, Varanasi, 2007, p.113

27. Paradakar SH, editor. Ashtang Hridaya, Sutrasthana. Reprint edition. Ch. 1, Ver. 7, Varanasi: Chaukhamba Sanskrit Sansthan; 2010. p.8.

28. Didangelos, A., Yin, X., Mandal, K., Baumert, M., Jahangiri, M., Mayr, M.; Proteomics Characterization of Extracellular Space Components in the Human Aorta; Molecular \& Cellular Proteomics; 2010, 9(9): 2048-2062

29. Paradakar SH, editor. Ashtang Hridaya, Sutrasthana. Reprint edition. Ch. 12, Ver. 2, Sarvangasundari commentary by Arunadatta, Varanasi: Chaukhamba Sanskrit Sansthan; 2010. p. 195

30. Paradakar SH, editor. Ashtang Hridaya, Sutrasthana. Reprint edition. Ch. 1, Ver. 13, Ayurvedarasayana commentary by Hemadri, Varanasi: Chaukhamba Sanskrit Sansthan; 2010. p. 10 .

31. Ann Burgess E, B. Sylven; Glucose, Lactate, and Lactic Dehydrogenase Activity in Normal Interstitial Fluid and That of Solid Mouse Tumors; Cancer Res;1962 (22), 581-588

32. Kajimura M, M. E. O'Donnell and F. E. Curry; Effect of cell shrinkage on permeability of cultured bovine aortic endothelia and frog mesenteric capillaries; Journal of Physiology (1997), 503(2), p. $413-425$

33. Acharya Y.T., Charaka Samhita, reprint edition, Nidanasthana, Ch.4, Ver.37, Ayurved-dipika commentary by Chakrapani, Chaukhamba Orientalia, Varanasi, 2007, p.215

34. Paradakar SH, editor. Ashtang Hridaya, Nidanasthana. Reprint edition. Ch. 14, Ver. 18,
Ayurvedarasayana commentary by Hemadri, Chaukhamba Sanskrit Sansthan, Varanasi, 2010. p.525.

35. Mahadevan L.; Colour Atlas and Handbook of Ayurvedic Dermatology \&Venerology; SaradaMahadevaIyerAyurvedic Educational and Charitable Trust; $2^{\text {nd }}$ Edition, 2014, p.74

36. Acharya Y.T., Charaka Samhita, reprint edition, Chikitsasthana, Ch.21, Ver.15, Ayurved-dipika commentary by Chakrapani, Chaukhamba Orientalia, Varanasi, 2007, p.559

37. Sharma R.K., Bhagwan Dash; CharakaSamhita English translation; Chaukhamba Sanskrit Series Office, Varanasi, Vol.IV, Chikitsasthana, 21/3, 1979, p.259

38. Paradakar SH, editor. AshtangHridaya, Nidanasthana. Reprint edition. Ch. 14, Ver. 26, Ayurvedarasayana commentary by Hemadri, Chaukhamba Sanskrit Sansthan, Varanasi, 2010. p.526.

39. Mahadevan L.; Colour Atlas and Handbook of Ayurvedic Dermatology \&Venerology; Sarada Mahadeva Iyer Ayurvedic Educational and Charitable Trust; $2^{\text {nd }}$ Edition, 2014, p.51

40. Schultz G, Ladwig G, Wysocki A; Extracellular matrix: Review of its roles in acute and chronic wounds; World Wide Wounds, August 2005. www.worldwidewound.com

41. Helge Wiig; Pathophysiology of tissue fluid accumulation in inflammation; J Physiol. 2011 Jun $15 ; 589$, p.2945-2953

42. Mukesh Sonawane, Satish Nimse; C-Reactive protein: a major inflammatory biomarker; Anal. Methods, 2017, 9, 3400-3413 